"Accounting systems in developing countries under sustainability: first glance from Ukraine and Ghana"

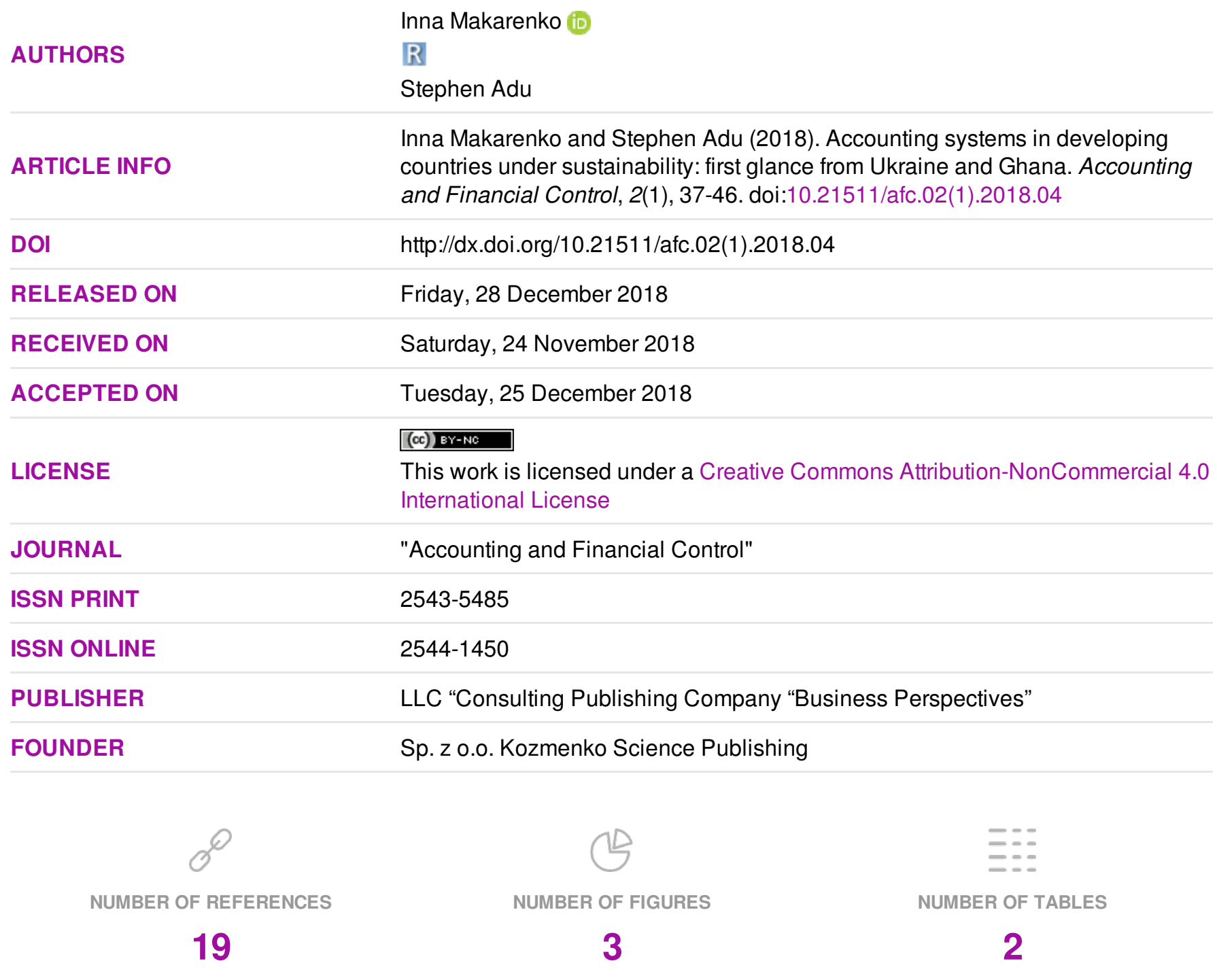

(c) The author(s) 2023. This publication is an open access article. 


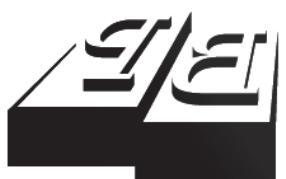

BUSINESS PERSPECTIVES

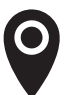

LLC "CPC "Business Perspectives" Hryhorii Skovoroda lane, 10, Sumy, 40022, Ukraine

www.businessperspectives.org

Received on: $24^{\text {th }}$ of November 2018 Accepted on: $25^{\text {th }}$ of December 2018

(C) Inna Makarenko,

Stephen Adu, 2018

Inna Makarenko, Doctor of Economics, ACCA DipIFR, Associate Professor of Accounting and Tax Department, Sumy State University, Ukraine.

Stephen Adu, Lecturer at the Faculty of Business Administration, Ghana Baptist University College, Ghana.

\section{(ㄷ)(1) $(9$}

This is an Open Access article, distributed under the terms of the Creative Commons Attribution-NonCommercial 4.0 International license, which permits re-use, distribution, and reproduction, provided the materials aren't used for commercial purposes and the original work is properly cited.

\begin{abstract}
The dissemination of sustainability reporting and integrated reporting is a key trend in the development of accounting systems under the influence of the concept of sustainable development. This statement is fair not only for developed countries, but also for developing countries. On the example of Ghana and Ukraine, a comparative study of regulatory requirements and conceptual frameworks for the compilation of sustainability reporting and integrated reporting has been conducted; the dynamics, size of reporting companies, their sectoral affiliation and the standards used are researched. It was proved that the basis for the promotion sustainability reporting and integrated reporting in these countries are regulatory requirements, as well as increasing the perception of CSR, the transparency and accountability of business, the practices of stakeholder participation and assurance the reliability of reporting for stakeholders.
\end{abstract}

\section{Keywords}

JEL Classification accounting system, sustainability, integrated reporting, Ukraine, Ghana

M40, M48, Q01

\title{
INTRODUCTION
}

A key trend in the corporate reporting development is disclosure in accordance with the priority requests of stakeholders, not only financial information, but also social and environmental indicators of companies' activities.

Transforming stakeholder information expectations and increasing the companies' information transparency has led to the spread of sustainability reporting (SR) in general and the emergence of integrated reporting (IR) as a unique and universal format for information disclosure.

The demand for such reporting by key stakeholders - investors, employees, consumers, the public is steadily increasing. At the same time, the regulation of the procedure for this reporting compilation, submission, assurance of quality and reliability for stakeholders, its integration into accounting and analytical support of companies is a challenge for accounting systems of different countries.

This challenge determines the direction of transformation of these systems not only in developed countries (as traditionally considered in academic sources (Cheng et al., 2014; Eccles et al., 2010; Eccles \& Saltzman, 2011; Dragu, \& Tiron-Tudor, 2013)). It begins to play an important role in developing countries (Ioannou \& Serafeim, 2011), in particular Ghana (Toit et al., 2014), Tsamenyi et al. (2007) and Ukraine (Petryk et al., 2018; Makarenko \& Sirkovska, 2017, Mynhardt et al. (2017). 
With SR and IR wide spreading these countries and their companies are gaining competitive advantage in terms of increasing transparency of business environment, investment attractiveness and positive image of companies, consumer loyalty.

The research of SR and IR of these countries seems even more relevant than for developed countries, given the need to increase the transparency of companies.

Drivers of innovations in accounting systems today are government regulators, financial sector regulators and stock exchanges, as well as newly established institutions that develop their own codes, conceptual frameworks and standards for SR and IR (Institute of Directors in Southern Africa, 2009), International Integrated Reporting Council (IIRC ) (2013),

The most spread requirements to SR disclosure are state authority instruments (80\% from 64 countries provide such regulations. These requirements concern large and listing companies first of all: from 250 world largest companies SR and IR disclosure level is $93 \%$.

Financial regulators and stock exchanges provide additional rules for these companies' transparency: $73 \%$ of mandatory SR disclosure instruments were developed for them. Especially for these companies. For example, IR as well as King III Code of Governance Principles is mandatory for all listing companies in South African Republic.

The practical aspect of the study is described on the example of two developing countries - Ukraine and Ghana. The accounting systems of these countries are at the initial stage of the introduction of SR and IR and require significant changes on the path to sustainable development. Comparative study of main regulatory issues, current state of companies SR and IR disclosure is rather important for the search of instruments, ways and methods for business environment transparency.

Paper reminder is presented as follows: description of regulatory requirements in Ghana and Ukrainian accounting system (both from public and financial regulators) - part 1; analysis of current state of integrated and sustainability reporting in large companies - part 2; key challenges and perspectives in accounting system development under sustainability and conclusions - part 3.

\section{THEORETICAL BASIS}

\subsection{Regulatory requirements as a basis of Ghana and Ukrainian accounting system in sustainable world}

\subsubsection{Ghana accounting regulation and $S R$}

\section{Companies Act}

The Companies Code 1963 (Act 179) applies to all listed and private companies. Though, the Act is old and in need of revision and upgrading in line with the contemporary environment. The code does not provide for IR and SR, it explicitly provides for presentation and preparation of statemen of performance, statement of financial position, statement of cash flows, relevant explanations of company's operations and transactions, directors' report and auditor's report. Requires companies to prepare annual statutory financial statements that comply with the Companies Act disclosure requirements and Ghana National Accounting Standards (which are IFRS). Thus, presently the Companies code is not a useful tool for the promotion of IR in the country.

\subsubsection{Ghana stock exchange listing rules}

Securities and Exchange Commission Ghana (SECG) and Ghana Stock Exchange (GSE) regulate financial reporting practices of listed companies.

GSE requires listed companies to prepare annual 
statutory financial statements that comply with the Ghana National Accounting Standards (which are IFRS since 2007). Quarterly reports must be prepared and submitted.

The Annual Report must be prepared in accordance with the Companies Act and the Securities and Exchange Commission Regulations

The following must be listed in the Report.

- A Statement showing directors shareholdings at the Reporting date

- Details of material contracts during the year involving directors' interest

- Statement detailing the number of holders of each class of equity security, voting rights for each class and the names of the 20 largest holders of each class of equity security together with percentage

- The name of company directors, secretary, solicitors, external auditors, and share registrars

- The address and telephone number.

\subsubsection{Requirements to get listed on the Ghana stock exchange.}

- Minimum Stated Capital: It must have a stated capital after the public floatation of at least GH $\$ 1$ million in the case of an application relating to the First Official List and GHc0.25 million for the Ghana Alternative Market (GAX).

- Minimum Public Float: Shares issued to the public must not be less than twenty-five percent $(25 \%)$ of the number of issued shares of the company.

- Payment of Shares: Shares must be fully paid for: Except in very exceptional circumstances, the Exchange will refuse to list in respect of partly paid shares.

- $\quad$ Spread of Shares: The spread of shareholders existing at the close of an offer should be in the GSE's opinion adequate with at least 100 shareholders after the public offer for the Main Board and 20 for the Ghana Alternative Market (GAX).

A review of the Ghana Stock Exchange (GSE) listing requirements showed that they do not make state or reference to SR and IR. They further stipulate that this "statement may be contained in a separate section of the annual report and need not be audited".

All in all, the IR framework in Ghana seems underdeveloped. The framework seems to be based on the Ghana companies code it lacks the right details with regard to SR and IR hence in need of upgrading. Moreover, although Ghana stock exchange Guidelines for Listed Companies were given to the custody of the GSE, listing requirements do not reflect the same, and this has the potential to produce uncertainty to the preparers of annual reports of the listed companies. Consequently, there must be harmonization.

\subsection{Ukraine accounting regulation and SR}

The key challenges in national accounting system in sustainability context are as follows:

1) further convergence of accounting models of Ukraine and the $\mathrm{EU}$ in the application of IFRS;

2) introduction of companies' SR and IR, in particular, the management report, the report on corporate governance and the country-bycountry reporting and ensuring its verification for the benefit of a wide range of stakeholders.

Basic requirements for SR disclosure were stipulated by the Law of Ukraine "On Accounting and Financial Reporting in Ukraine" in accordance with Association Agreement with the EU from the $27^{\text {th }}$ of June, 2014 and Ukraine obligation to implement Directive 2013/34/EU of the European Parliament and of the Council of 26 June 2013 on the annual financial statements, consolidated financial statements and related reports of certain types of undertakings and Directive 2014/95/EU of the European Parliament and of the Council of 22 October 2014 amending Directive 2013/34/EU as regards disclo- 
sure of non-financial and diversity information by certain large undertakings and groups.

These obligations are derived from the Article 293 Trade favoring sustainable development (Chapter 13 Trade and Sustainable Development) of Association Agreement with the EU. They prescribe to conduct responsible business practices and SR disclosure by Ukrainian companies entering European markets and transpose abovementioned European accounting Directives.

Two types of SR are described in Law of Ukraine "On Accounting and Financial Reporting in Ukraine":

- management report - a document containing financial and non-financial information that characterizes the state and prospects of companies' development and reveals the main risks and uncertainties of its activities;

- report on payments in favor of the state - a document containing summary information on the activities of business entities engaged in extractive industries or timber harvesting, as well as detailed information on taxes and duties, other payments that have been paid or payable on the benefit of the state in accordance with the law.

There are such categories of companies, obliged to present SR with individual or consolidated financial reporting under IFRS for the year ended in 2018:

- public interest entities:

1) issuers of securities whose securities are listed on the stock exchanges:

2) banks,

3) insurers,

4) non-state pension funds,

5) other financial institutions:

- $\quad$ large enterprises (which do not meet the criteria for medium-sized enterprises and whose indicators on the date of preparation of the annual financial statements for the year pre- ceding the reporting period corresponds to at least two of the following criteria:

1) the book value of assets - more than 20 million euros;

2) net income from the sale of products (goods, works, services) - more than 40 million euros,

3) the average number of employees - more than 250 people).

The management report is presented in conjunction with the financial statements and the consolidated financial statements in the manner and in accordance with the terms established by law. If consolidated financial statements are presented to the company, a consolidated management report is submitted. Microenterprises and small enterprises are exempted from the management report submission. Mediumsized enterprises have the right not to display nonfinancial information in the management report.

Report of payments in favor of the state (equivalent of the government payment report or countryby- country reporting in Directive 2014/95/EU) is provided by economic entities operating in the extractive industries in accordance with the Law of Ukraine "On ensuring transparency in the extractive industries", as well as companies engaged in harvesting timber and thus representing public interest

No additional listing requirements are provided by stock exchanges or financial regulators in Ukraine. National Securities and Stock Market Commission obliges listed companies to disclose their reports on corporate governance with annual information presented to Commission ("On Approval of the Regulation on Disclosure of Information by Issuers of Securities" Decision dated 03.12.2013, No. 2826). However, this report does not provide non-financial or sustainability information.

\section{RESULTS}

Empirical study of companies' sustainability and integrated reporting in Ghana and Ukraine was based on GRI SDD data set. Companies reports were collected and analyzed as of December 1, 2018. 
Source: compiled by the authors according to GRI SDD (2018).

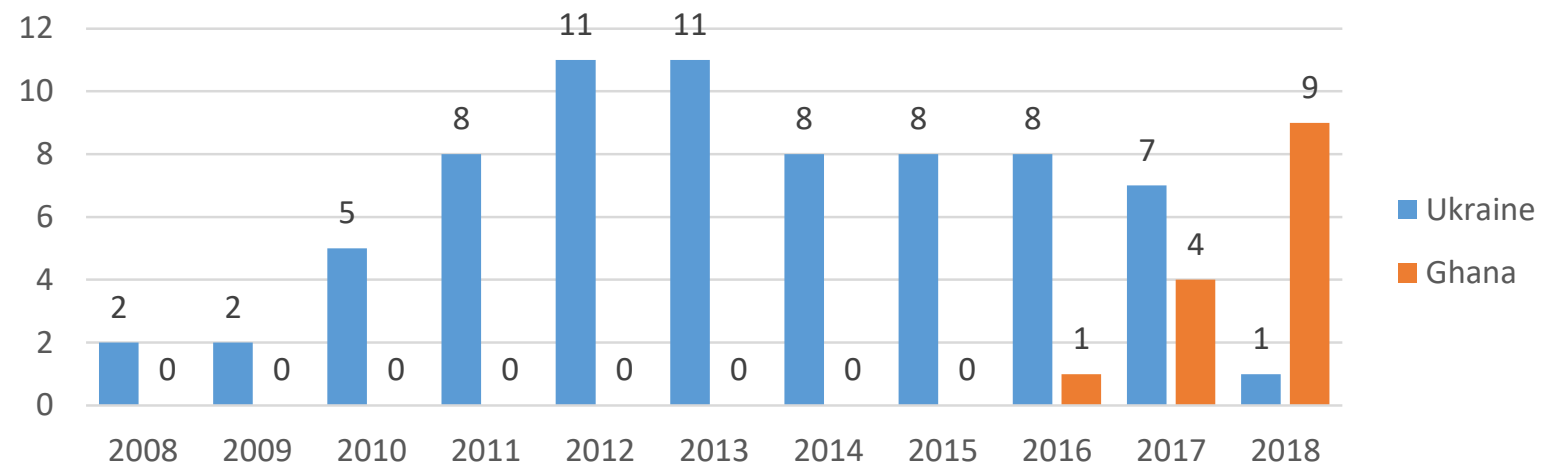

Figure 1. Number of SR in Ghana and Ukraine for the period of 2008-2018

Researched sample contains 13 companies with 14 reports from Ghana and 21 companies with 70 reports from Ukraine for the period 2008-2018.

Comparative study of companies' sustainability and integrated reporting in Ghana and Ukraine covers such issues as:

- dynamics of sustainability and integrated reporting in Ghana and Ukraine;

- $\quad$ sector and size analysis;

- the most used accounting standards.

In the first area of analysis (Figure 1) it is worth noting that the quantity of SR disclosed by companies in Ghana and Ukraine is rather small due to initial stage of CSR activity spreading.

The first SR in Ukraine was published in 2005. Pioneers in non-financial reporting in Ukraine were VidiGroup (2005), DTEK (2007) and Kyivstar (2007). But these reports are not presented in SDD GRI.

We can distinguish two main sub-period in sustainability disclosure by Ukrainian companies:

- 2010-2013 - constant growth in sustainability reporting publishing with peak in 2012-2013. These years were favorable to companies and business activity after global financial crisis 2007-2009;

- 2014-2017 - steady reporting pace, with low rate of companies' disclosure during econom- ic recession period. These years were characterized by complex economic and political situation in Ukraine and sharp decrease in business activity. Leaders in sustainability reporting in Ukraine from the occupied East cut their disclosure.

2018 is not indicative because of some companies publish their reports with 1- or 2-year lags. It depends on their accounting and reporting cycle type.

Ghana companies SR reports are mainly presented in recent years - for the reporting periods of 2017-2018. This tendency shows the rise of interest in CSR, SR and IR reporting in Ghana.

Size analysis of SR for the period of 2008-2018 (Figure 2) shows that mainly large Ukrainian companies published such reports in 2012-2017 and only by these companies in 2008-2011 and 2018 .

MNE (multinational entities) SR were published by SCM holding and Arcelor Mittal Kryvyj Rig. They are companies with large part of non-resident investments and with developed system of CSR activity and disclosure.

Large companies were represented by companies, which also have a significant part of foreign investment and incorporate CSR model into its activity on stakeholder (esp. shareholder) demand or new Ukrainian companies, which have an opportunity to operate on European markets or were listed on European stock markets.

In Ukraine, the formal provisions of Directive 2014/95/EU are fulfilled by largest companies, 


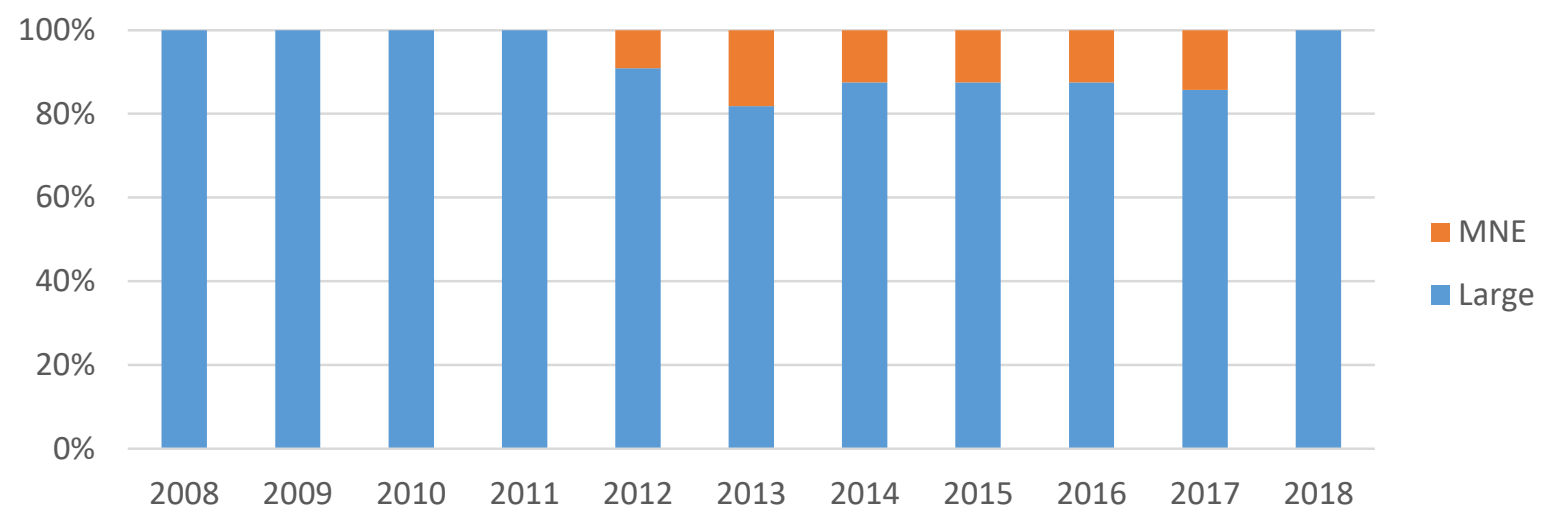

Figure 2. SR in Ukraine for the period of 2008-2018 by the companies' size

which obviously have the greatest impact and opportunities for promoting sustainable development initiatives by means of reporting.

At the same time, sample of large and MNE companies analyzed is so small among whole quantity of large Ukrainian companies. This fact additionally indicates the low prevalence and perceptions of CSR and sustainable development in the ideology of Ukrainian society.

Unlike Ukraine, Ghana companies published SR and IR are most Small and Medium Sized - 9 reports from 14. Nevertheless, 4 large entities represent financial institution - banks and their SR and IR are expected at the nearest future - at the year ended 2018. Therefore, the size structure of Ghana companies SR should be revised.

Sectorial analysis of SR in Ukraine (Table 1) shows that leading sectors in disclosure of non- financial information are Food and Beverage Products (12 reports), Metals Products (10 reports), Agriculture, Financial Services (9 reports).

The majority of companies with sustainability disclosure practice concentrates in custom oriented sectors as Food and Beverage Products, Financial Services or sectors with negative influence on ecology (Agriculture, Metals Products).

Sector analysis of Ghana companies shows that leading sector is Financial services: 3 financial institution (Access Bank Ghana, Aluworks Ltd, HFC Bank Ltd) publish their reports in 2016-2017.

Other sectors like Agriculture, Food and Beverage Products, Textiles and Apparel uniformly represented by 2 SME companies in 2018.

Table 1. SR in Ukraine for the period of 2008-2018 by the companies' sector

Source: compiled by the authors according to GRI SDD (2018).

\begin{tabular}{|c|c|c|c|c|c|c|c|c|c|c|c|c|}
\hline Sector & 2008 & 2009 & 2010 & 2011 & 2012 & 2013 & 2014 & 2015 & 2016 & 2017 & 2018 & Total \\
\hline Agriculture & 0 & 0 & 0 & 0 & 0 & 1 & 1 & 2 & 2 & 2 & 1 & 9 \\
\hline Metals products & 0 & 0 & 0 & 1 & 2 & 3 & 1 & 1 & 1 & 1 & 0 & 10 \\
\hline Commercial services & 0 & 0 & 0 & 2 & 1 & 1 & 1 & 1 & 0 & 1 & 0 & 7 \\
\hline Financial services & 0 & 0 & 1 & 1 & 2 & 2 & 1 & 0 & 1 & 1 & 0 & 9 \\
\hline Energy & 0 & 0 & 0 & & 1 & 1 & 1 & 1 & 1 & 1 & 0 & 6 \\
\hline Other & 0 & 0 & 1 & 1 & 2 & 1 & 0 & 1 & 0 & 1 & 0 & 7 \\
\hline $\begin{array}{l}\text { Food and beverage } \\
\text { products }\end{array}$ & 0 & 1 & 1 & 1 & 2 & 1 & 3 & 1 & 2 & 0 & 0 & 12 \\
\hline Telecommunications & 1 & 1 & 1 & 1 & 1 & 1 & 0 & 1 & 1 & 0 & 0 & 8 \\
\hline Mining & 1 & 0 & 1 & 0 & 0 & 0 & 0 & 0 & 0 & 0 & 0 & 2 \\
\hline Total & 2 & 2 & 5 & 7 & 11 & 11 & 8 & 8 & 8 & 7 & 1 & 70 \\
\hline
\end{tabular}


Table 2. SR in Ghana for the period of 2008-2018 by the companies' sector

\begin{tabular}{|c|c|c|c|}
\hline & 2016 & 2017 & 2018 \\
\hline Agriculture & 0 & 0 & 2 \\
\hline Energy & 0 & 1 & 0 \\
\hline Financial services & 1 & 3 & 0 \\
\hline Construction materials & 0 & 0 & 1 \\
\hline Other & 0 & 0 & 2 \\
\hline Food and beverage products & 0 & 0 & 2 \\
\hline Textiles and apparel & 0 & 0 & 2 \\
\hline Total & 1 & 4 & 9 \\
\hline
\end{tabular}

As for the specific of sustainability reporting preparation, the GRI approach is prevailing (Figure 3). At the same time, in Ukraine the GRI system by the number of companies' supporters $(53 \%)$ is slightly higher than companies using free-form reporting (47\%). Given the focus of reports of Ukrainian companies in 2010-2013 years, the most used is GRI-G3 standard. The last of the applicable standards in Ukraine is GRI-Standard, a reference to which in their reports was provided only by Astarta.

It should be stressed that in Ghana, the most used accounting methodology for SR presentation is the latest version of GRI Standards, pub- lished in 2016. 9 SME companies used it in 2018, unlike 4 large companies. Other conclusions and trend analysis concerning Ghana companies rather difficult to made due to small sample examined.

Besides the studied reporting standards, the continuous research of published reports by Ukrainian companies in the part of chosen CSR standards leads to the conclusion that the main type among them is the UNGC. Disclosure of 10 basic principles of contract in communication report on the progress as a sustainability reporting form is a characteristic for $83.0 \%$ of Ukrainian companies. However, formally Ukrainian companies-members of the Global Compact comply with Directive 2014/95/EU as for a selected basis for standardization of their CSR initiatives.

Particular attention should be paid to the integrated presentation format of sustainability reporting and financial reporting: only in Obolon report for 2014 its compliance with IIRC requirements is declared.

Summing up, it should be noted that low level of spread and perception of CSR among Ukrainian and Ghana companies and the lack of a single national framework for sustainability reporting as well as accounting methodology are the main reason of low rates in sustainability disclosure.

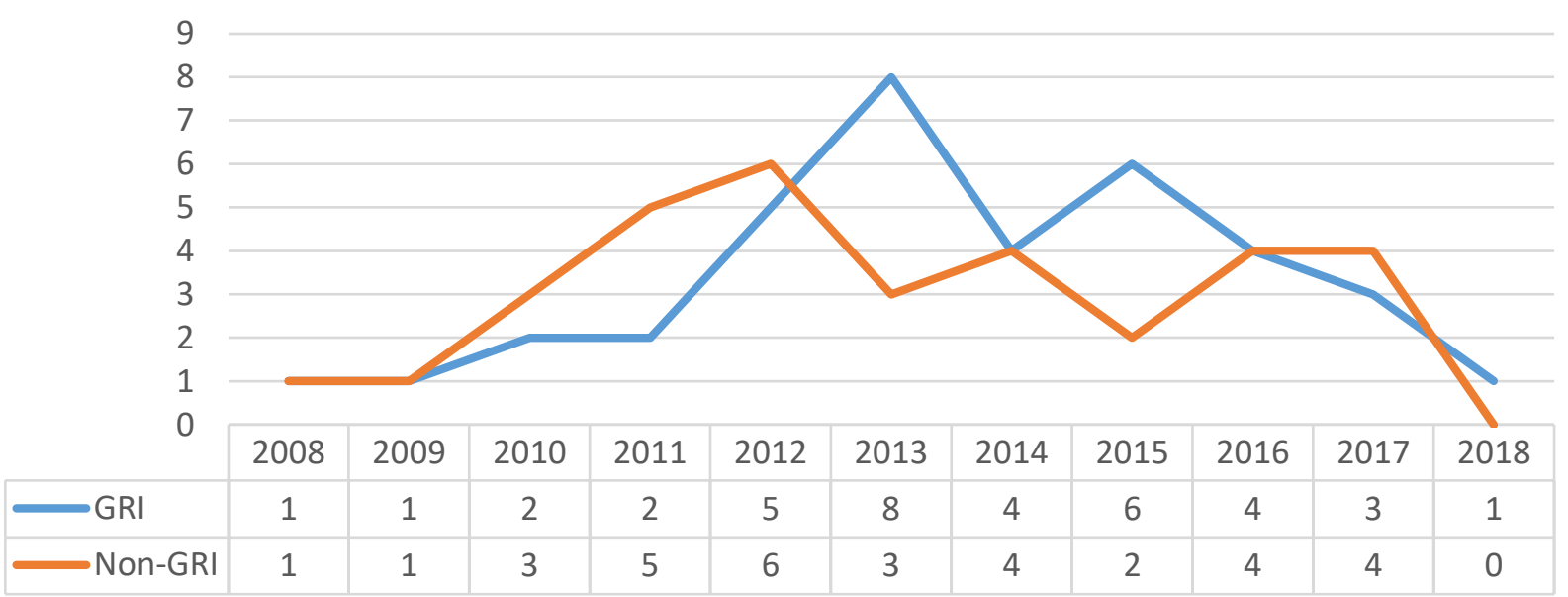

Figure 3. Standards for preparation sustainability reporting in the EU and Ukraine in 1999-2016 


\section{CONCLUSION}

In the context of SR and IR introduction in Ukraine and Ghana it worth to say that the both countries are in initial stage of its implementation and wide spreading among companies.

Ghana legislation and listing requirements does not provide obligation for companies to publish SR or IR. At the same time, some non-financial reports have been introduced in Ukraine recently.

As our analysis of dynamics, sector issues show, companies from different sectors in Ukraine and Ghana publish their SR and IR with growing pace, mostly in accordance with GRI framework. IR framework has not used yet massively. Main differences between the disclosure practice in these developing countries is the size of companies reported. SME companies play a leading role as SR reporters in Ghana, unlike Ukraine.

Common issue in accounting system development under sustainability for both companies is low level of demand for SR and IR from the main categories of their stakeholder.

Main reasons of these situation and key challenges of SR and IR reporting in Ukraine and Ghana are

- low level of CSR perception and understanding in society and among stakeholders;

- low transparency of business environment, company's accountability, dominance of financial reporting practice and regulation;

- low level of stakeholder engagement in company's management and decision-making process and strategy;

- initial stage of accounting, reporting and assurance methodology of SR and low level of its credibility and relevance for stakeholders.

The consequences of low-level perception of CSR and SR disclosure in developing countries decrease their competitiveness, reducing the innovation and investment potential of the economy.

There are problematic issues, special for Ukraine. It is further implementation of EU accounting legislation (Directives 2014/95/EU and 2013/34/EU) and developing methodology of disclosure of the corporate governance report (the management report) and the government payments report (country-bycountry reporting) in accordance with Directives.

There are no detailed requirements regarding the form and procedure for the provision and publication of these two reports in the law. It is noted only that the procedure and terms for submitting a report on management and a report on payments in favor of the state to state authorities are determined by the Cabinet of Ministers of Ukraine, for banks - by the National Bank of Ukraine.

However, the detailed procedure for compiling, submitting and publishing, the report form for these categories of enterprises is not given, which makes it difficult to prepare such a report for the results of 2018.

The research provides practical insight on the areas that need improvements in the promotion of IR in Ghana and Ukraine. It contributes to the understanding of the current SR and IR framework in developing countries. The study further adds to the extant literature on accounting system transformation under sustainability in developing countries and serves as a future reference point. 
The study has some limitations. It evaluated the annual report from GRI database. Future research should assess individual companies annual report over time to recognize the progress over the years and expand the sample that includes other corporate and SR database in order to have a comprehensive picture.

\section{ACKNOWLEDGEMENT}

Inna Makarenko gratefully acknowledges financial support from the Ministry of Education and Science of Ukraine "Corporate social and environmental responsibility for sustainable development: stakeholders' partnership in the real, financial and public sectors of the economy" (0117U003933).

\section{REFERENCES}

1. Cheng, M., Green, W., Conradie, P., Konishi, N., \& Romi, A. (2014). The International Integrated Reporting Framework: Key Issues and Future Research Opportunities. Journal of International Financial Management \& Accounting, 25(1), 90-119. http://dx.doi. org/10.1111/jifm.12015

2. Directive 2013/34/EU of the European Parliament and of the Council of 26 June 2013 on the annual financial statements, consolidated financial statements and related reports of certain types of undertakings, amending Directive 2006/43/EC of the European Parliament and of the Council and repealing Council Directives 78/660/EEC and 83/349/ EEC. Retrieved from http://eurlex.europa.eu/legal-content/EN/ ALL/?uri=CELEX:32013L0034

3. Directive 2014/95/EU of the European Parliament and of the Council of 22 October 2014 amending Directive 2013/34/EU as regards disclosure of nonfinancial and diversity information by certain large undertakings and groups, Official Journal of the European Union L 330/1. Retrieved from http://eur-lex. europa.eu/legal-content/EN/ TXT/?uri=CELEX:32014L0095

4. Dragu, I.-M., \& Tiron-Tudor, A. (2013). New Corporate Reporting Trends: Analysis on the Evolution of Integrated Reporting. Annals of Faculty of Economics, 1(1), 1221-1228. Retrieved from http:// steconomiceuoradea.ro/anale/volume/2013/n1/129.pdf
5. Eccles, R. G., \& Saltzman, D. (2011). Achieving Sustainability through Integrated Reporting. Stanford Social Innovation Review, 9(3), 56-61.

6. Eccles, R. G., Cheng, B., \& Saltzman, D. (2010). The Landscape of Integrated Reporting. Reflections and Next Steps (334 p). Harvard Bussines School.

7. Eccles, R. G., Serafeim, G. (2014). Corporate and Integrated Reporting: A Functional Perspective. (HBS Working Paper No. 14-094). Retrieved from https://hbswk. hbs.edu/item/corporate-andintegrated-reporting-a-functionalperspective

8. European External Action Service (EEAS) (27.06.2014). EU-Ukraine Association Agreement. Retrieved from http://eeas.europa.eu/ archives/delegations/ukraine/eu_ ukraine/association_agreement/ index_en.htm

9. Ghana Stock Exchange (2018). Listing requirements. Retrieved from https://www.african-markets. com/en/stock-markets/gse/listedcompanies

10. GRI SDD Database (2018). Retrieved from http://database. globalreporting.org/search

11. Institute of Directors in Southern Africa (IoDSA) (2009). King Code of corporate governance for South Africa 2009. Retrieved from http://c.ymcdn.com/sites/ www.iodsa.co.za/resource/ collection/94445006-4F184335-B7 FB-7F5A8B23FB3F/
King_Code_of_Governance_for SA_2009_Updated_June_2012.pdf

12. International Integrated Reporting Council (IIRC) (2013). The International Integrated Reporting Framework. Retrieved from http:// www.theiirc.org/wp-content/ uploads/2013/12/13-12-08-THEINTERNATIO NAL-IR-FRAMEWORK-2-1.pdf

13. Ioannou, I., \& Serafeim, G. (2011). The Consequences of Mandatory Corporate Sustainability Reporting (HBS Working Paper No. 11-100). Retrieved from http://hbswk.hbs. edu/item/the-consequences-ofmandatory-corporate-sustainability-reporting

14. Makarenko, I., \& Sirkovska, N. (2017). Transition to sustainability reporting: evidence from $\mathrm{EU}$ and Ukraine. Business ethics and Leadership, 1(1), 16-24.

15. Mynhardt, H., Makarenko, I., \& Plastun, O. (2017). Standardization of sustainability reporting: rationale for better investment decision-making. Public and $\mathrm{Mu}$ nicipal Finance, 6(2), 7-15.

16. Petryk, O., Kurylo, O., Karmaza, O., Makhinchuk, V., \& Martyniuk, O. (2018). Non-financial reporting of companies and the necessity of its confirmation by auditors in Ukraine. Problems and Perspectives in Management, 16(2), 385395. http://dx.doi.org/10.21511/ ppm.16(2).2018.3

17. Toit, A., Steyn, B., Pilley, A., \& Gweshe, R. (2014). Insights into SOC Integrated Reporting 
Trends in South Africa. Journal of Management Research, 7(3), 130-

156. http://dx.doi.org/10.5296/jmr. v7i3.7195

18. Tsamenyi, M., Enninful-Adu, E., \& Onumah, J. (2007). Disclosure and corporate governance in de- veloping countries: evidence from Ghana. Managerial Auditing Journal, 22(3), 319-334. http://dx.doi. org/10.1108/02686900710733170

19. Verkhovna Rada of Ukraine (1999). Закон України «Про бухгалтерський облік та фінансову звітність в Україні» від 16.07.1999 № 996-XIV [Law of Ukraine "On Accounting and Financial Reporting in Ukraine" 16.07.1999 No. 996-XIV]. Retrieved from http://zakon4.rada. gov.ua/laws/show/996-14 